\title{
Correction to: Closed but Not Protected: Excess Deaths Among the Amish and Mennonites During the COVID-19 Pandemic
}

\author{
Rachel E. Stein ${ }^{1}$ D $\cdot$ Katie E. Corcoran ${ }^{1} \cdot$ Corey J. Colyer ${ }^{1} \cdot$ Annette M. Mackay $^{1}$. \\ Sara K. Guthrie ${ }^{1}$
}

Published online: 17 February 2022

(c) Springer Science+Business Media, LLC, part of Springer Nature 2022

\section{Correction to: Journal of Religion and Health (2021) 60:3230-3244 https://doi.org/10.1007/s10943-021-01307-5}

In the original publication of the article, the statement of the funding information section was incorrectly published. This has been corrected with this erratum.

Funding This research was funded by the National Science Foundation, grant number 2048683, the International Research Network for the Study of Science \& Belief in Society (IRN Grant SFSRG01/114), and the West Virginia University Humanities Center.

Publisher's Note Springer Nature remains neutral with regard to jurisdictional claims in published maps and institutional affiliations.

The original article can be found online at https://doi.org/10.1007/s10943-021-01307-5.

Rachel E. Stein

rachel.stein@mail.wvu.edu

1 Department of Sociology and Anthropology, West Virginia University, PO Box 6326,

Morgantown, WV 26506-6326, USA 